\title{
KEPEMIMPINAN NON MUSLIM DI INDONESIA PERSPEKTIF HUKUM ISLAM
}

\author{
Oleh: \\ Muhammad Jufri \& Ahmad Dahlan \\ Universitas Ibrahimy Situbondo \\ m.jufritujuhtiga@gmail.com
}

\begin{abstract}
:
There is a difference of opinion related to the non-muslim skill of being a leader. Differences are: The first is not allowed, the second may be in the realm of the executive only, and also the third may be conditional. For Muslims chosen non Muslim as the leader of the law is the same with non-Muslim law becomes the leader.
\end{abstract}

Key Words: Pemimpin non-Muslim, Indonesia, Hukum Islam.

\section{A. Pendahuluan}

Manusia sebagai khalifah dimuka bumi ini merupakan penganugrahan pemberian kekuasaan dari Allah. Ada 2 kekuasaan yang diberikan Allah kepada manusia, kekuasaan umum yaitu memakmurkan kehidupan dimuka bumi, dan kekuasaan khusus yaitu kekuasaan untuk sebagai pemerintah disuatu negara. Kekuasaan kenegaraan ini dapat diberikan kepada sebuah negara ataupun individu- individu tertentu. ${ }^{1}$ Kekuasaan yang diberikan oleh negara berarti manusia terbebas dari kedzaliman, kebudakan, berdaulat dan mampu melindungi kepentingankepentingan umat. Kekuasaan yang diberikan kepada individu- individu yaitu pemerintah sebuah negara. Pemerintah atau pemimpin sebuah negara itu biasa dikenal dengan khalifah, Imam, peresiden dan lainnya.

Mengangkat sebuah pemimpin merupakan kewajiban kifayah bahkan bila hanya ada satu orang saja yang layak untuk dijadikan pemimpin maka bagi dia wajib ain untuk menjadi pemimpin. ${ }^{2}$ Menurut Mujar Ibnu Syarif, mengangkat sebuah pemimpin merupakan perkara

${ }^{1}$ Abdul Qadir Audah, al- Mal wal Hukmi fi al-Islam (Bairut: Mansyurat al-Ashar, 1971), hlm. 72.

2 Abu Yahya Muhyiddin Syarif an-Nawawy, raudah at-Thalibin wa Umdah alMuftiin (bairut: al-Maktabah al-Islamy, 1991), jilid 10, hlm. 44. 
yang urgen, karena tidak mungkin dalam sebuah negara tanpa adanya pemimpin yang akan melindungi dan mengatur negara tersebut. ${ }^{3}$

Keberadaan kepala negara bukan hanya untuk melindungi rakyat saja akan tetapi untuk terjaminnya segala perintah dan hukum Allah. Karena dengan itu ibnu taimiyah mengatakan bahwa " empat puluh tahun negara yang dipimpin oleh orang yang dzalim lebih baik dari pada negara yang satu malam saja tanpa kepala negara. ${ }^{4}$

Penegasan dalam mengangkat sebuah pemimpin didukung oleh dalil seperti hadits berikut:

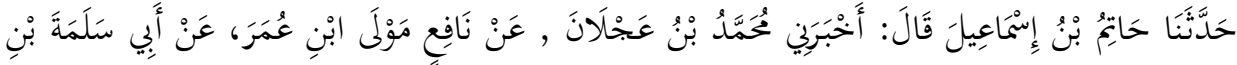

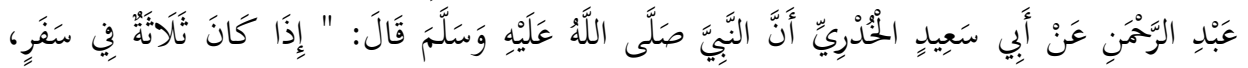

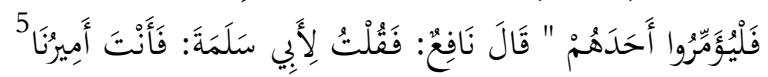

"jika ada tiga orang hendak bepergian maka hendaknya salah satunya dijadikan pemimpin." (HR.Abu Daud)

Adapun tata cara pengangkatan pemimpin dalam islam ada 2 cara yaitu: Pertama, dipilih oleh ahlu al-halli wa al-aqdi. Orang yang diberikan kepercayaan untuk memilih tersebut haruslah orang yang adil, memiliki wawasan yang bisa menetukan siapakah orang yang berhak untuk menjadi pemimpin dengan memperhatikan syarat-syarat dari pada pemimpin tersebut, dan memiliki pandangan dan hikmah yang bisa menentukan siapakah yang lebih pantas dan lebih mengetahui untuk dijadikan pemimpin dan mengurus rakyat. Model ini sebagaimana yang dilakukan sahabat ketika hendak memilih khalifah setelah wafatnya Rosulullah SAW. Kedua, penunjukan dari imam sebelumnya. ${ }^{6}$

Indonesia merupakan negara yang sudah melakukan kewajiban kifayah tersebut karena diIndonesia semenjak dinyatakan merdeka sudah ada pemimpinnya masing-masing dari tingkat paling tinggi yaitu presiden sampai tingkatan terendah yang ada di desa yaitu kepala desa. Pertama kali Indonesia mengadakan pemilu yaitu pada tanggal 29 september 1955. Pemilu ini diikuti oleh banyak partai dengan aneka ragam partai politik. Ada 29 partai politik yang ikut dalam pemilu ini. Selain itu, terdapat 46

3 Mujar Ibnu Syarif, Doktrin dan Pemikiran Politik Islam (Bandung: Erlangga, 2008), hlm. 97.

4Ibnu Taimiyyah, as-Syiyasyah as-Syar'iyyah Islah ar-Ra'yi wa ar-Arraiyyah (riyadh: Maktabah salafiyyah wa Maktabatuha, 1964), hlm. 91.

${ }^{5}$ Abu Daud, Sunan Abi Daud (lebanon: Darul Kutub, 1996), jilid II, hlm. 241.

${ }^{6}$ Al-Mawardi, "al-Ahkam al-Sulthaniyyah" (Mesir: Musthafa, 1973), hlm. 6.

$60 \quad$ JURNAL LISAN AL-HAL 
kelompok organisasi, 59 orang mewakili perorangan dan 34 kelompok kumpulan. Semuanya memperebutkan 257 kursi dari 15 daerah pemilihan. ${ }^{7}$ Pemilihan pemimpin di Indonesia harus diusung oleh partai politik. Namun akhir-akhir ini sangat memanas tentang perbincangan pemimpin non muslim diIndonesia, entah itu untuk kepentingan politik ataukah bukan. Secara fakta dari dulu Indonesia memang pernah ada pemimpin yang non muslim terbukti pada tabel berikut:

Data Gubernur Non Muslim di Indonesia Tahun $2013^{8}$

\begin{tabular}{|c|l|l|l|}
\hline N0 & Nama & Jabatan didaerah & Agama \\
\hline 1 & Frans Lebu Raya & Gubernur di NTT & $\begin{array}{l}\text { Kristen } \\
\text { katolik }\end{array}$ \\
\hline 2 & Cornelis & $\begin{array}{l}\text { Gubernur di } \\
\text { kalimantan barat }\end{array}$ & $\begin{array}{l}\text { Kristen } \\
\text { katolik }\end{array}$ \\
\hline 3 & $\begin{array}{l}\text { Agustinus Teras } \\
\text { Narang }\end{array}$ & $\begin{array}{l}\text { Gubernur di } \\
\text { kalimantan tengah }\end{array}$ & $\begin{array}{l}\text { Kristen } \\
\text { protestan }\end{array}$ \\
\hline 4 & $\begin{array}{l}\text { Sinyo Harry } \\
\text { Sarundajang }\end{array}$ & $\begin{array}{l}\text { Gubernur di sulawesi } \\
\text { utara }\end{array}$ & Kristen \\
\hline 5 & $\begin{array}{l}\text { Karel Albert } \\
\text { Ralahalu }\end{array}$ & Gubernur di maluku & Kristen \\
\hline 6 & $\begin{array}{l}\text { Abraham } \\
\text { Octavianus Atururi }\end{array}$ & $\begin{array}{l}\text { Gubernur di papua } \\
\text { barat }\end{array}$ & $\begin{array}{l}\text { Kristen } \\
\text { katolik }\end{array}$ \\
\hline
\end{tabular}

\section{B. Asas- asas pemilu di Indonesia}

Dalam budaya demokrasi, cara pemilihan pemimpin adalah melalui pemilihan umum. Mengenai ketentuan pemilihan umum diatur dalam UU. No.12 Tahun 2003. Adapun ketentuan tersebut diantaranya: ${ }^{9}$

1. Langsung. Rakyat sebagai pemilih mempunyai hak untuk memberikan suaranya secara langsung sesuai dengan kehendak hati nuraninya tanpa perantara.

2. Umum. Pada dasarnya semua warga negara yang memenuhi persyaratn sesuai dengan UU ini berhak mengikuti pemilu. Pemilihan yang bersifat umum mengandung makna yang menjamin kesempatan yang berlaku menyeluruh bagi semua warga negara tanpa diskriminasi berdasarkan

7 Thabrani Shabirin, Mengantar Bangsa Menuju Demokrasi (Jakarta: KPU-LPSI, 2000), hlm. 24.

8 https://www.nahimunkar.com/daftar-nama-gubernur-kristen-di-Indonesia2013-dan-diusung-oleh- partai//20-05-2017/10:00 Wib

9 Rizkiyansyah, Ferry Kurnia, , Mengawali Pemilu Menatap Demokrasi (Catatan Penyelenggaraan Pemilu 2004). ( Bandung: Idea Publishing, 2007), hlm. 24. 
suku, agama, ras, golongan, jenis kelamin, kedaerahan, pekerjaan dan status sosial.

3. Bebas. Setiap warga negara yang berhak memilih bebas menentukan pilihannya tanpa tekanan dan paksan dari siapapun. Didalam melaksanakan haknya setiap warga negara dijamin keamanannya sehingga dapat memilih sesuai dengan kehendak hati nurani dan pertimbangannya.

4. Rahasia. Dalam memberikan suaranya, pemilih dijamin bahwa pilihannya tidak akan diketahui oleh pihak manapun dan dengan jalan apapun. Pemilih memberikan suaranya pada surat suara dengan tidak dapat diketahui oleh orang lain kepada siapapun suaranya diberikan.

5. Jujur. Dalam penyelenggaraan pemilu, aparat pemerintah, peserta pemilu, pengawas pemilu, pemantau pemilu, pemilih serta semua pihak yang terkait harus bersikap dan bertindak jujur sesuai dengan peraturan UU.

6. Adil. Dalam penyelenggaraan pemilu, setiap pemilih dan peserta pemilu mendapat perlakuan yang sama, serta bebas dari kecurangan pihak manapun. Jadi, ada tambahan dalam asas demokrasi dalam pemilu Tahum 2004 bila dibandingkan dengan pemilu sebelumnya, yaitu asas jujur dan adil.

Secara prinsip, tambahan asas tersebut dalam produk yuridis memiliki konsekuensi hukum, yaitu harus ditegakkan dengan memberikan sanksi bagi pelanggarnya. Hal ini menunjukkan adanya kesadaran baru rakyat bahwa pemilu yang baik haruslah dilandasi oleh prinsip kejujuran dan keadilan sehingga dapat diperoleh sistem perwakilan yang representatif.

\section{Gambaran Umum Negara Demokrasi}

\section{Pengertian dan Dasar-Dasar Negara Demokrasi}

Negara merupakan bentuk wilayah kedaulatan yang berisi kumpulan masyarakat yang memiliki tujuan yang sama. Secara konseptual setiap negara memiliki ciri khas dan model pemerintahannya sendirisendiri, tergantung bagaimana konteks dan tuntutan masyarakat yang membentuk dan mewarnai corak pemerintahan negara tersebut. Demokrasi secara etimologi berasal dari dua gabungan kata Yunani, yakni demos (rakyat) dan kratos (pemerintah) atau dalam bahasa ringkasnya 'pemerintahan oleh rakyat'. Kiranya Athena, salah satu kota di Yunani, tempat pertama tercetusnya ide sistem politik demokrasi. Adalah Plato (428-374 SM) yang kemudian mengusulkan terbentuknya pemerintahan yang dikemudikan oleh orang bijak. Ia cemas jika 
mengamalkan arti demokrasi dalam artian 'pemerintahan oleh rakyat' akan meledak anarki. Aristoteles (384-322 SM) muridnya kemudian mengembangkan pendapat Plato yang tetap memberikan ruang bagi pendapat rakyat. Dan Aristoteles pulalah yang kemudian, berusaha mengkombinasikan antara sistem pemerintahan monarki dengan demokrasi. ${ }^{10}$ Karena menurutnya pemerintahan yang merupakan gabungan antara demokrasi dan monarki adalah pemerintahan yang ideal. ${ }^{11}$

Sementara Emha Ainun Najib menggambar negara demokrasi bak perawan sebagaimana perkataannya: "Demokrasi itu bak "perawan", yang merdeka dan memerdekakan. Memiliki watak 'mempersilahkan', tidak punya konsep menolak, menyingkirkan, atau membuang. Semua makhluk penghuni kehidupan berhak hidup bersama si perawan, bahkan berhak memperkosanya: yang melarang memperkosa bukan si perawan itu sendiri, melainkan "sahabat"-nya yang bernama moral dan hukum".12

Adapun dasar-dasar dari dari pada Negara Demokrasi adalah pertama, sumber kekuasaan secara keseluruhan adalah rakyat, artinya kekuasaan tertinggi adalah rakyat sementara para pejabat pemerintahan merupakan wakil dari pada rakyat. Sehingga yang harus diperhatikan pejabat didalam bertindak adalah kemaslahatan untuk rakyat secara umum, sebagaimana ketentuan dalam bab wakalah bahwa wakil harus melakukan apa-apa yang dikehendaki orang yang mewakilkan dan bernilai maslahat baginya. Apabila tindakan wakil tidak sesuai dengan ketetntuan tersebut wakil berhak memecatnya dalam artian mengkudeta dan apa-apa yang dilakukan menjadi batal. Kedua, semua orang memiliki kebebasan untuk berfikir, berbicara menyampainya inspirasinya, bertindak sesuai kehendaknya senyampang tidak melanggar hukum yang telah berlaku, dan beraqidah sesuai keyakinan masing-masing dari pada ajaran yang rakyat yakini. Ketiga, penyamarataan terhadap semua rakyat tanpa membedakan ras, agama, miskin, kaya, dan status sosialnya. Artinya didalam hukum mereka semua sama. Keempat, menjaga harga diri rakyat dan kemulyaanya. ${ }^{13}$

\section{Persamaan antara Negara Islam dan Negara Demokrasi} hlm. 19.

${ }^{10}$ Eko Prasetyo, “Demokrasi Tidak Untuk Rakyat” (Yogyakarata: Resist Book, 2005),

${ }^{11}$ Aristoteles, "Politik (La Politika)" (Jakarta:Visimedia, 2007), vii.

12 Emha Ainun Najib, "Demokrasi La Raiba Fih" (Jakarta: Penerbit Buku Kompas, 2009), hlm. 50.

13 Muhammad Zakariyya an-Nadaf, "al-Akhlak al-Siyasiyyah li al-Daulah alIslamiyyah" (Damaskus: Dar al-Qalam, 2006 ), hlm. 436. 
Negara Islam dan Negara Demokrasi memiliki parbedaan dan persamaan sehingga ada yang menganggap negara Demokrasi itu sama dengan Negara Islam. Disamping ada yang menggap sama juga ada yang menggap bahwa negara Demokrasi berbeda dengan Negara Islam dengan alasan dasar-dasar dari pada Negara Demokrasi itu menyimpang dari dasar-dasar dari pada Negara Islam. Ini hanya memperhatikan dari sebagian hakikatnya saja, sementara ketika diperhatikan dari hakikat yang sempurna maka antara Negara Islam dan Negara Demokrasi ini perbedaannya sama dengan kesamaannya. Tapi terkadang yang lebih benar itu mengatakan bahwa perbedaannya yang lebih banyak atau perbedaan itu lebih penting dari pada aspek kesamaannya. ${ }^{14}$

Adapun persamaan antara Negara Islam dengan Negara Demokrasi antara lain: ${ }^{15}$ 1) Dipandang dari Aspek Pemusatan Pedudukan terhadap Rakyat, Hubungan antara Penguasa dengan yang dikuasai dan pertanggung jawaban politik; 2) Adanya Dasar-Dasar Politik dan Organisasi tertentu seperti dasar kesamaan dimata undang-undang, kebebasan berfikir dan beraqidah, terwujudnya keadilan yang bersifat umum, terjaganya hak seperti hak hidup, merdeka dan melakukan sesuatu selama tidak menyimpang dari hukum; 3) Hukum kerakyatannya melalui rakyat dan untuk rakyat dalam artian alat hukum adalah rakyat; dan 4) Adanya penamaan disetiap pemegang wewenang.

\section{Perbedaan antara Negara Islam dan Negara Demokrasi}

Adapun perbedaan antara Negara Islam dan Negara Demokrasi antara lain:

a. Misi dari masing-masing negara. Negara Islam memilki misi yang bersifat dunia dan akhirat, sementara Negara Demokrasi misinya hanya bersifat dunia saja yaitu untuk mensejahterakan rakyat seperti dinaikkannya gaji dan lainnya.

b. Kekuasaan ummat. Negara Islam kekuasaan umat dibatasi terhadap syariat islam sehingga undang-undangnya bersifat moral dan apa-apa yang sudah menjadi ketetapan syariat dengan melalui nash maka tidak ada ranah untuk diamandemen. Sementara di Negara Demokrasi kekuasaan umat bersifat mutlak sekalipun itu tidak sesuai dengan kemaslahatan manusia secara umum.

\footnotetext{
14 Muhammad Dayya'u al-Din al-Rais, "al-Nadariyyah al-Siyyasiyyah al-Islamiyyah" (Kairo:Dar al-Turats, 1976), hlm. 378.

15 Muhammad Zakariyya an-Nadaf, "al-Akhlak al-Siyasiyyah li al-Daulah alIslamiyyah" (Damaskus: Dar al-Qalam, 2006), hlm. 437-439.
}

64 JURNAL LISAN AL-HAL 
c. Negara Demokrasi bersamaan dengan pemikiran yang sifatnya kerakyatan sehingga ini meniscayakan terhadap adanya pemikiran yang fanatisme. Sementara di Negara Islam tidak begitu karena pemikiran dalam Negara Islam itu bersifat kemanusiaan yang sesuai dengan sesuatu yang bersifat ilmiyyah. ${ }^{16}$

\section{Pertimbangan dalam Pemilihan Pemimpin}

Muhammad Zakariyya an-Nadaf mengatakan bahwa yang perlu diperhatikan dalam pemilihan pemimpin yaitu fiqh al-Waqi'. ${ }^{17} \mathrm{Al}-\mathrm{Mawardi}$ mengandaikan apabila ada 2 orang calon, yang pertama dia berilmu sementara yang kedua pemberani maka untuk memilihnya haruslah sesuai dengan perkara yang dibutuhkan oleh kedudukan yang akan ditempati, seandainya kedudukan tersebut membutuhkan terhadap orang yang berilmu karena banyaknya golongan yang ahli bid'ah didaerah tersebut maka yang lebih berhak untuk menempati kedudukan tersebut adalah orang yang berilmu akan tetapi, seandainya kedudukan tersebut membutuhkan orang yang pemberani karena didaerah tersebut tampak orang yang memberontak maka yang lebih berhak untuk menduduki kedudukan tersebut adalah orang yang memiliki sifat keberanian.18 Berdasarkan hal tersebut maka ulama' ahli sunnah sepakat mengangkat orang yang lebih utama karena ada kemaslahatan yang diunggulkan dipandang dari kebutuhan kedudukan tersebut. ${ }^{19}$

\section{Pandangan Fiqh Terhadap Kepemimpinan Non Muslim}

Negara Demokrasi merupakan negara yang kepemimpinannya langusng dipilih oleh rakyat. Dan tidak bisa dipungkiri bahwa salah satu dari calon bukan merupakan muslim. Al-Mawardi dalam kitab al-Ahkam al-Sulthaniyyah membagi kedudukan menjadi 2 yaitu pertama bagian eksekutif (وزارة تنفيذdan yang kedua bagian legislatif (وزارةتفويض). Dalam hal ini al-Mawardi membolehkan anggota eksekutif dari selain muslim karena anggota eksekutif ini merupakan perantara antara imam dan rakyat

\footnotetext{
16 Muhammad Zakariyya an-Nadaf, "al-Akhlak al-Siyasiyyah li al-Daulah alIslamiyyah" (Damaskus: Dar al-Qalam, 2006), hlm. 437.

17 Muhammad Zakariyya an-Nadaf, "al-Akhlak al-Siyasiyyah li al-Daulah alIslamiyyah" (Damaskus: Dar al-Qalam, 2006 ), hlm. 144.

${ }_{18}$ Al-Mawardi, "al-Ahkam as-Sulthaniyyah" (Iskandar:Dar ibn Khaldun,tth), hlm. 9.

19 Yahya Ismail, "Manha as-Sunnah fi al-Alaqoh baina al-Hakim wa al-Mahkum" (Mansurah:Dar al-Wafa',1994), hlm. 257.
}

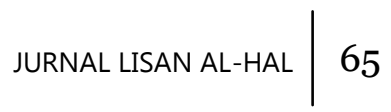


sehingga apa-apa yang dilakukan anggota eksekutif ini harus sesuai dengan pandangan imam. ${ }^{20}$

Ali Syibromilisi mengatakan bahwasanya mengangkat non muslim untuk urusan orang muslim itu tidak akan tetapi apabila hanya dia (non muslim) yang mampu untuk melaksanakan urusan tersebut, atau orang muslim sudah berkhianat sementara orang non muslim sanggup untuk mengemban amanah tersebut dan tidak berhianat maka, boleh non muslim diberikan kekuasaan karena adanya kemaslahatan dari pemberian kekuasaan tersebut. ${ }^{21}$

Disisi lain imam Badruddin al-Hamawi juga tidak membolehkan non muslim dijadikan pemimpin untuk mengurusi urusan orang-orang islma akan tetapi, kalau ternyata kedudukan kepemimpinan tersebut hanya mengurusi urusan orang-orang non muslim yang ada pada daerah tersebut beliau justru membolehkan, seperti pejabat pemungut pajak bagi non muslim. Adapun dasar yang digunakan dalam hal tersebut adalah , sementara mengangkat non muslim yang mengurusi kepentingan muslim itu termasuk memberi jalan terhadap non muslim berbeda halnya untuk mengurusi urursan non muslim juga. ${ }^{22}$

Sementara Qodi Iyad juga berkomentar dalam hal ini bahwasanya ulama' telah sepakat tentang tidak sahnya pengangkatan pemimpin bagi non muslim bahkan keluarnya dari agama islam bagi seorang pemimpin itu merupakan sebab dari pada dipecatnya pemimpin tersebut. Dasar dari pada pendapat ini sama dengan dasar yang dilontarkan oleh Badruddin alHamawi. ${ }^{23}$

Imam Zainuddin al-Malibari sepertinya menganggap keabsahan pemimpin non muslim karena didalam bab Qada' tentang pengangkatannya sultan terhadap hakim disana terdapat ghoyah setelah kata sultan 24 dengan begitu seakan-akan Zainuddin al-Malibari menganggap sah kepemimpinan non muslim walaupun didalam I'anah althalibin dikomentari oleh Abu Bakar al-Syatha bahwasanya lebih tepat ghoyah tersebut diletakkan setelah lafad ذو شوكة karena syarat dari pada

${ }^{20}$ Al-Mawardi, "al-Ahkam al-Sulthaniyyah" (Mesir: Musthafa, 1973), hlm. 25.

21 Ibnu Hajar al-Haitami, "Tuhfah Muhtaj fi Syarh al-Minhaj" (Mesir: Maktabah altijariyyah al-Kubro, 1983), jilid 9, hlm. 73.

22 Badruddin al-Hamawi, "Tahrir al-Ahkam fi Tadbiri Ahlu al-Islam" (Maktabah Syamilah: Dar al-tsaqofah, 1977), hlm. 146.

${ }^{23}$ Abu Zakariya Muhyiddin bin Syaraf al-Nawawi, " al-Minhaj Syarh Shahih Muslim bin Hajjaj” (Bairut: Dar al-Ihya', 1971), jilid 12, hlm. 229. hlm. 137.

${ }^{24}$ Zainuddin al-Malibari, "Fath al-Mu'in" (Surabaya: Maktabah Imaratullah, tth),

66 JURNAL LISAN AL-HAL 
seorang pemimpin adalah muslim dan kepemimpinan orang kafir itu tidak sah. ${ }^{25}$

\section{E. Pandangan Fiqh Terhadap Memilih Pemimpin Non Muslim}

Dari paparan tentang menjadikan pemimpin non muslim sebagai pemimpin lantas bagaimana terkait dengan rakyat yang menggunakan hak pilihnya untuk mendukung non muslim sebagai pemimpin?. Tentu untuk menghukumi ini kita harus tidak menutup mata terhadap uraian pendapat tentang pemimpin non muslim tersebut, karena ini merupakan konsekuensi dari pada uraian diatas. Arti lain hukum ini sesuai dengan hukum yang ada pada uraian diatas karena

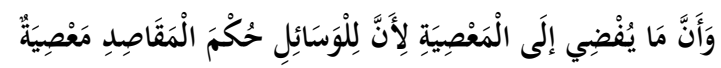

"Sesungguhnya perantara hukumnya sama dengan yang ditujunya dan sesungguhnya perkara yang mengantarkan kepada kemaksiatan itu juga maksia".26

Dalam hal ini al-Razi menggolongkan keadaan muslim yang mengangkat non muslim sebagai wali ada 3 bagian: Pertama, dia rido terhadap kekafirannya dan memilih dia sebagai pemimpin karena kekafirannya tersebut dan ini dilarang karena akan menyebabkan kekafiran dengan beralasan bahwa orang yang rido dengan kekafiran itu juga tergolong kafir. Kedua, sebatas pergaulan yang baik saja secara dohir, dalam artian tidak meridoi terhadap kekafiran tersebut. Dalam golong yang kedua ini tidaklah dilarang oleh syara'. Ketiga, golongan ini diantara kedua golong diatas. Dalam golongan ini dia mengangkat tersebut dengan arti percaya kepada orang tesebut dan menolongnya disebabkan orang tersebut merupakan kerabatnya atau mencintainya dengan tetap meganggap bahwa agamanya salah. Perlakuan dari golongan ini juga dilarang meskipun tidak menyebabkan terhadap kekafiran seperti halnya golongan pertama karena mengangkat non muslim sebagai pemimpin dengan alasan tersebut terkadang mengantarkan kepada memberikan ruang lingkup terhadap mereka dan rido terhadap agamanya yang dapat mengeluarkan seseorang muslim dari keislamannya. ${ }^{27}$ 215.

${ }^{25}$ Abu Bakar al-Syatha, "I'anah al-Thalibin” (Surabaya: Dar al-Ilmi, tth), jilid 4, hlm.

${ }^{26}$ Muhammad Ibn Muhammad Ibn Musthafa Ibn Utsman Abu Sa'id al-Khadimy alHanafy, "Bariqoh Mahmudiyyah fi Syarhi Thariqoh Muhamdiyyah wa Syari'ah Nubuwiyyah fi Sirah Ahmadiyyah" (Maktabah syamilah: Matba'ah al-halabi, 1985), jilid 4, hlm. 5.

27 Fahruddin al-Razy, "Mafatih al-Ghoib” (Bairut: Dar Ihya' al-Turats al-Araby, 1983), jilid 8, hlm. 192. 
Sejalan dengan pendapat al-Razy yaitu imam Nawawi banten yang sama-sama membagi 3 golongan orang yang memilih pemimpin non muslim sebagai pemimpin. Yang yang sama-sama mengatakan kebolehan bagi golongan yang kedua sebagaimana yang dikatan oleh al-Razy. Dalam golongan kedua ini imam nawawi banten menyebutkan bahwa pada golongan kedua ini yaitu sebagai bentuk dari pada pergaulan yang baik di dunia tapi sebatas dahir saja sehingga perbuatan yang seperti ini tidak dilarang. ${ }^{28}$

\section{F. Tujuan dari Adanya Pemimpin}

Setiap apa-apa yang diharuskan bahkan diwajibkan tentunya memiliki tujuan tesendiri sebagaimana di wajibkannya adanya seorang pemimpin ini menurut al-Mawardi memiliki tujuan untuk menjaga agama dan mensiyasati kehidupan di dunia karena seandainya tidak ada seorang pemimpin niscaya akan terjadi kekacauan. ${ }^{29}$ Bahkan Ibn Taymiyyah menyamakan daerah yang tidak memiliki pemilik seperti binatang tanpa adanya penggembalanya.

Negara Demokrasi memiliki tujuan tersendiri tentang keharusan adanya pemimpin. Dengan melihat terhadap dasar-dasar dari pada Negara Demokrasi, tujuannya adalah mensejahterakan kehidupan rakyat. Tujuan ini sesuai dengan misi dari pada negara demokrasi tersebut yang telah dijelaskan sebelumnya. Perbedaan ini telah disebutkan tentang misi dari pada masing-masing dari negara tersebut yang mana misi dari pada Negara Islam itu adalah bersifat duniawi dan ukhrowi, sementara misi dari pada Negara Demokrasi ini hanya bersifat duniawi saja tidak ukhrowi.

\section{G. Ayat-Ayat Tentang Larangan Non Muslim dijadikan auliya'}

Banyak sekali ayat-ayat al-Qur'an yang dijadikan dalil tentang ketidak bolehan non muslim dijadikan pemimpin. Diantaranya:

a). Surat al-Baqarah ayat 120

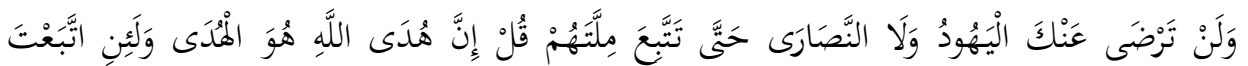

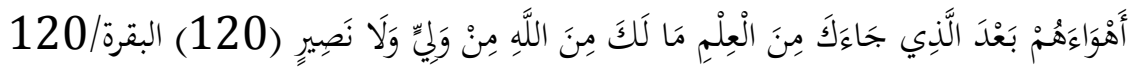

"Orang-orang Yahudi dan Nasrani tidak akan senang kepada kamu hingga kamu mengikuti agama mereka. Katakanlah: "Sesungguhnya petunjuk Allah

${ }_{28}$ Muhammad Ibn Umar al-Nawawi al-banteny, "murah libaidi likasyfi Makna alQur'an al-Majid” (Bairut: Dar al-Kutub Ilmiyyah, 1988), jilid 1, hlm. 120.

${ }^{29}$ Al-Mawardi, "al-Ahkam al-Suthaniyyah" (Mesir: Musthafa, 1973), hlm. 5. 
Itulah petunjuk (yang benar)". dan Sesungguhnya jika kamu mengikuti kemauan mereka setelah pengetahuan datang kepadamu, Maka Allah tidak lagi menjadi pelindung dan penolong bagimu"

b). Surat Ali Imron ayat 28

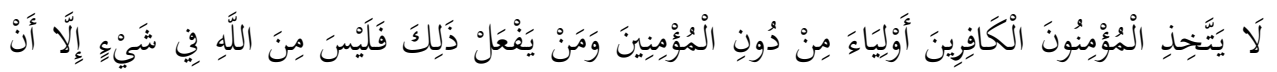

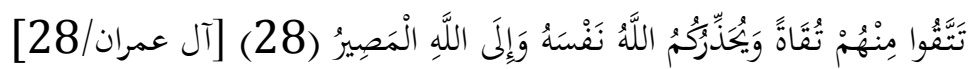

"Janganlah orang-orang mukmin mengambil orang-orang kafir menjadi wali dengan meninggalkan orang-orang mukmin. barang siapa berbuat demikian, niscaya lepaslah ia dari pertolongan Allah, kecuali Karena (siasat) memelihara diri dari sesuatu yang ditakuti dari mereka. dan Allah memperingatkan kamu terhadap diri (siksa)-Nya. dan Hanya kepada Allah kembali (mu)"

c). Surat an-Nisa' ayat 89

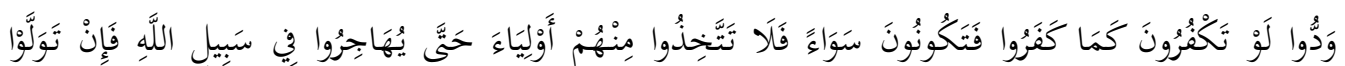

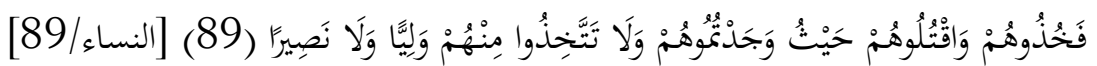

"Mereka ingin supaya kamu menjadi kafir sebagaimana mereka Telah menjadi kafir, lalu kamu menjadi sama (dengan mereka). Maka janganlah kamu jadikan di antara mereka penolong-penolong(mu), hingga mereka berhijrah pada jalan Allah. Maka jika mereka berpaling, tawan dan Bunuhlah mereka di mana saja kamu menemuinya, dan janganlah kamu ambil seorangpun di antara mereka menjadi pelindung, dan jangan (pula) menjadi penolong"

d). Surat an-Nisa' ayat 139

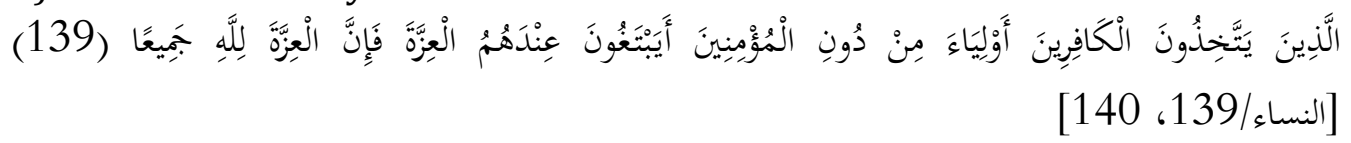

"(yaitu) orang-orang yang mengambil orang-orang kafir menjadi temanteman penolong dengan meninggalkan orang-orang mukmin. apakah mereka mencari kekuatan di sisi orang kafir itu? Maka Sesungguhnya semua kekuatan kepunyaan Allah"

e). Surat an-Nisa' ayat 144 


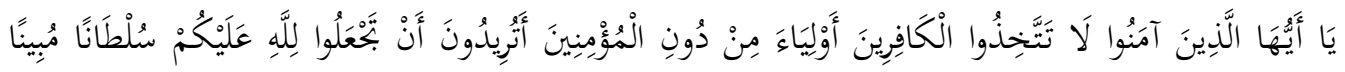

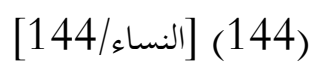

"Hai orang-orang yang beriman, janganlah kamu mengambil orang-orang kafir menjadi wali dengan meninggalkan orang-orang mukmin. Inginkah kamu mengadakan alasan yang nyata bagi Allah (untuk menyiksamu)?"

f). Surat al-Maidah ayat 51

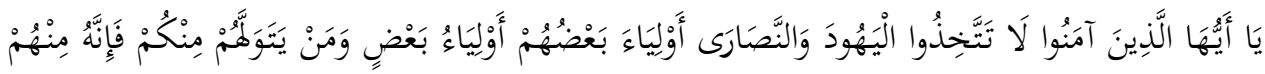

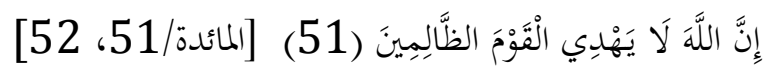

"Hai orang-orang yang beriman, janganlah kamu mengambil orang-orang Yahudi dan Nasrani menjadi pemimpin-pemimpin(mu); sebahagian mereka adalah pemimpin bagi sebahagian yang lain. barangsiapa diantara kamu mengambil mereka menjadi pemimpin, Maka Sesungguhnya orang itu termasuk golongan mereka. Sesungguhnya Allah tidak memberi petunjuk kepada orang-orang yang zalim"

g). Surat al-Maidah ayat 57

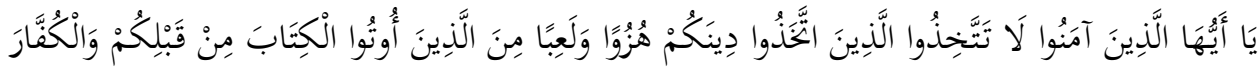

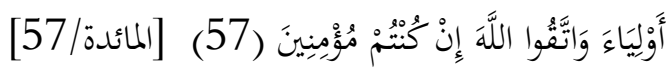

"Hai orang-orang yang beriman, janganlah kamu mengambil jadi pemimpinmu, orang-orang yang membuat agamamu jadi buah ejekan dan permainan, (yaitu) di antara orang-orang yang Telah diberi Kitab sebelummu, dan orang-orang yang kafir (orang-orang musyrik). dan bertakwalah kepada Allah jika kamu betul-betul orang-orang yang beriman"

h). Surat al-Maidah ayat 81

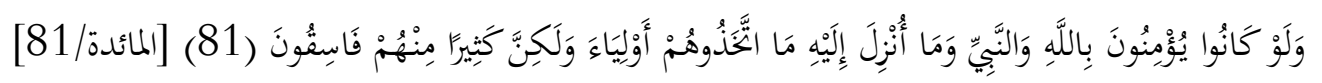

"Sekiranya mereka beriman kepada Allah, kepada nabi (Musa) dan kepada apa yang diturunkan kepadanya (Nabi), niscaya mereka tidak akan mengambil orang-orang musyrikin itu menjadi penolong-penolong, tapi kebanyakan dari mereka adalah orang-orang yang fasik"

70 $\mid$ JURNAL LISAN AL-HAL 
i). Surat at-Taubah ayat 23

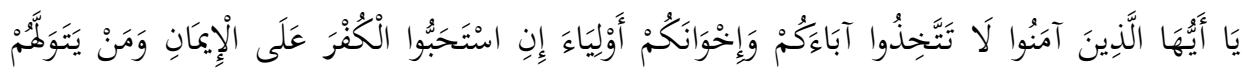

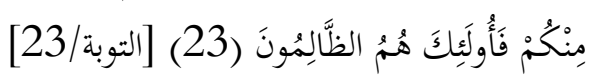

"Hai orang-orang beriman, janganlah kamu jadikan bapa-bapa dan saudara-saudaramu menjadi wali(mu), jika mereka lebih mengutamakan kekafiran atas keimanan dan siapa di antara kamu yang menjadikan mereka wali, Maka mereka Itulah orang-orang yang zalim"

j). Surat al-Mumtahanah ayat 1

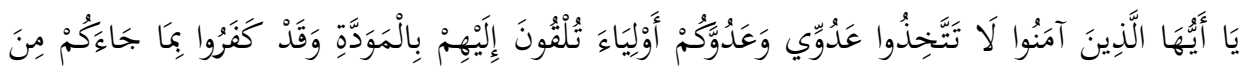

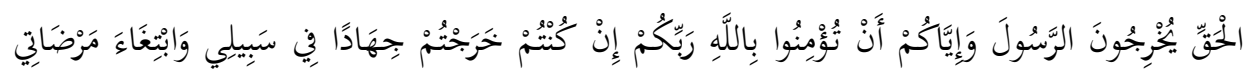

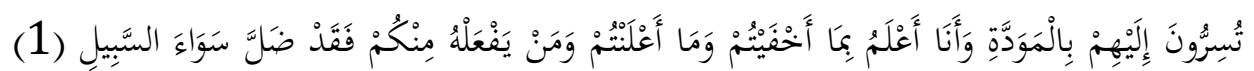

$$
\begin{aligned}
& \text { [1/ الممتحنة }
\end{aligned}
$$

"Hai orang-orang yang beriman, janganlah kamu mengambil musuh-Ku dan musuhmu menjadi teman-teman setia yang kamu sampaikan kepada mereka (berita-berita Muhammad), Karena rasa kasih sayang; padahal Sesungguhnya mereka Telah ingkar kepada kebenaran yang datang kepadamu, mereka mengusir Rasul dan (mengusir) kamu Karena kamu beriman kepada Allah, Tuhanmu. jika kamu benar-benar keluar untuk berjihad di jalan-Ku dan mencari keridhaan-Ku (janganlah kamu berbuat demikian). kamu memberitahukan secara rahasia (berita-berita Muhammad) kepada mereka, Karena rasa kasih sayang. Aku lebih mengetahui apa yang kamu sembunyikan dan apa yang kamu nyatakan. dan barangsiapa di antara kamu yang melakukannya, Maka Sesungguhnya dia Telah tersesat dari jalan yang lurus"

Dari ayat-ayat diatas yang dijadikan dasar untuk melarang pengangkatan non muslim sebagai pemimpin adalah kata auliya' yang diartikan pemimpin. Namun Quraisy shihab mengomentari bahwa kata tersebut diartikan pemimpin kurang tepat karena kata tersebut berasal dari akar kata wau, lam dan $y a^{\prime}$ yang memiliki arti dekat. Dari sinilah kemudian berkembang makna baru seperti: pendukung, pembela, pelindung, yang mencintai, lebih utama dan lain-lain, yang kesemuanya itu diikat oleh satu benang merah kedekatan. 
M. Quraisy shihab menuturkan penjelasan dari thabathaba'i, mufassir syi'ah. Bahwa dia mengartikan kata auliya' disesuaikan dengan kontek, karena kata tersebut merupakan satu bentuk kedekatan kepada sesuatu yang menjadikan terangkat dan hilangnya batas antara yang mendekati dan yang didekati dalam tujuan kedekatan itu. Kata tersebut kalau dalam kontek ketakwaan dan pertolongan maka berarti penolongpenolong; apabila dalam kontek pergaulan dan kasih sayang maka berarti ketertarikan jiwa sihingga kata tersebut tepatnya diartikan yang dicintai. Sementara dalam kontek hubungan kekeluargaan maka kata tersebut berarti yang mewarisinya dan tidak ada yang dapat menghalangi dari pewarisan tersebut. Dalam kontek ketaaan maka berarti siapa yang memerintah dan harus ditaati ketetapannya. Akan tetapi pada akhirnya thabathaba'i menyimpulkan bahwa yang dimaksudkan dalam ayat tersebut adalah cinta kasih yang dapat meleburkannya perbedaan dalam satu wadah, menyatunya jiwa yang tadinya berselisih, saling terkaitnya akhlaq dan miripnya tingkah laku, sehingga dua orang yang saling mencintai akan terlihat mamiliki satu jiwa, satu kehendak dan satu perbuatan, yang satu tidak akan berbeda dengan yang lain dalam perjalanan hidup dan tingkah pergaulan. ${ }^{30}$ Setelah dilacak terhadap kitabkitab tafsir ternyata kata auliya' kurang tetap apabila diartikan pemimpin. Karena ulama' mufassir dalam menafsiri kata tersebut sepertinya lebih mengarah kepada penolong. ${ }^{31}$

Dari paparan sebelumnya dapat dipahami bahwasanya kepemimpinan non muslim di Negara Demokrasi masih terjadi perbedaan pendapat. Ada yang tidak memberikan ruang kepemimpinan sama sekali bagi non muslim seperti Qadi Iyad bahkan, kafir itu dianggap sebagai sebab dari pada terpecatnya pemimpin.

Disamping itu, al-Mawardi memberikan ruang kepemimpinan terhadap non muslim akan tetapi tidak secara mutlak namun, hanya pada bagian tanfidiyyah/ eksekutif saja, karena pada bagian tanfidiyah/ eksekutif kebijakannya berpedoman terhadap kebijakan imam dalam artian yang mengontrol dari pada tindakan pejabat tanfidiyyah adalah imam sebab bagian tanfidiyyah/ eksekutif itu hanyalah pelaksana saja seperti gubernur dan lainya sementara yang mempunyai kebijakan untuk mengkonsep sebuah aturan adalah bagian tafwid. Ada 4 perbedaan antara

30 M. Quraisy Shihab, "Tafsir al-Misbah" (Tangerang: Lentera Hati, 2005), jilid 3, hlm. 123-124.

31 Ini merupakan kesimpulan dari beberapa kitab tafsir lihat Tafsir al-Thabary, Tafsir Ibnu Abbas, Tafsir Qurthuby, Lubabu al-Ta'wil fi Ma'any al-Tanzil, Tafsir al-Sya'rawy, Tafsir al-Wasiid al-Thanthawy, Tafsir al-Munir al-Zuhaily.

72 JURNAL LISAN AL-HAL 
bagian tafwid dan tanfid yaitu: pertama, terkait dengan kebolehan pejabat tafwid membuat suatu putusan dan melakukan perenungan terhadap hal tersebut secara langsung. Kedua, kebolehan bagi pejabat tafwid memiliki pemikiran tersendiri terkait dengan perihal ikut terhadap imam. Ketiga, kebolehan pejabat tafwid untuk bertindak mandiri didalam menggerakkan tentara dan mengatur siasat perang. Keempat, kebolehan pejabat tafwid mentasorrufkan baitul mal dengan cara memberikan apa yang wajib untuk dikeluarkan dan menyerahkan hak orang lain yang ada pada baitul mal tersebut. Semua kebolehan ini tidak bisa dilakukan oleh pejabat tanfid.

Ali Syibromilisi malah memberikan peluang bagi non muslim untuk menjadi seorang pemimpin ketika, hanya dialah yang bisa mengemban amanah kepemimpinan tersebut serta bersedia untuk mengemban amanah tersebut tanpa ada penghianatan, sementara orang islam sudah tidak dapat dipercaya lagi untuk mengemban amanah tersebut. Alasan dari pada kebolehan ini adalah demi tercapainya suatu kemaslahan untuk melakukan amanah tersebut.

Lain dari pada itu, Ibn Taymiyyah hanya memberikan 2 syarat bagi seorang pemimpin yaitu kuat dan amanah. Ibn taimiyyah sama sekali tidak mensyaratkan pemimpin muslim akan tetapi, dari pengertian amanah yang disyarakat oleh Ibnu Taimiyyah yaitu harus taqwa kepada Tuhan. disisi lain Dia lebih menekankan terhadap kesejahteraan rakyat terbukti dengan apa yang dia katakan dalam kitab ma'muj fatawa “ Allah SWT mendukung pemerintahan yang adil sekalipun kafir dan Allah SWT tidak mendukung pemerintahan yang dolim sekalipun muslim". Dari perkataan ini menunjukkan bahwa Ibn Taimiyyah didalam memberikan syarat bagi seorang pemimpin lebih memikirkan kesejahteraan rakyat.

Mewakili ulama' dari Indonesia yaitu Quraisy Shihab dalam menafsiri ayat-ayat tentang larangan menjadikan non muslim sebagai auliya' menyimpulkan bahwa larangan tersebut dikokohkan oleh 3 hal yaitu pertama, pada larangan yang menyatakan, janganlah kamu menjadikan orang-orang yahudi dan nasrani sebagai pemimpin. Kedua, penegasan bahwa sebagian mereka adalah pemimpin bagi sebagian yang lain. Ketiga, ancaman bagi yang mengangkat mereka sebagai pemimpin, bahwa ia termasuk golongan mereka serta merupakan orang yang zalim. Dengan begitu larangan tersebut tidaklah mutlaq, sehingga mencakup makna yang dikandung oleh kata auliya'.

Dalam hal ini Quraisy Shihab mengutip penjelasan sayyid Thantawi yang membagi non muslim terhadap 3 kelompok. Pertama, mereka yang tinggal bersama kaum muslimin, dan hidup damai bersama mereka, tidak melakukan kegiatan untuk kepentingan lawan islam serta tidak juga 
nampak dari mereka tanda-tanda yang mengantarkan kepada prasangka yang buruk terhadap mereka. Kelompok ini mempunyai hak dan kewajiban sosial yang sama dengan kaum muslimin. Tidak ada larangan untuk bersahabat dan berbuat baik kepada mereka, sebagaimana firman Allah:

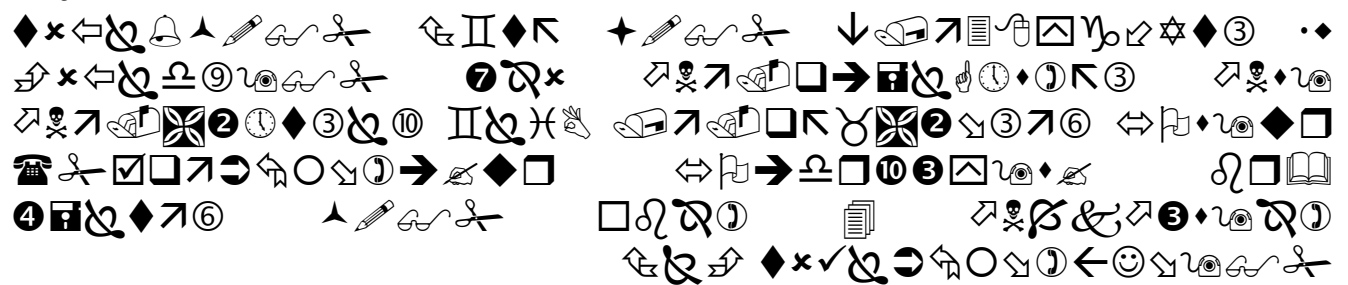

"Allah tidak melarang kamu untuk berbuat baik dan berlaku adil terhadap orang-orang yang tiada memerangimu Karena agama dan tidak (pula) mengusir kamu dari negerimu. Sesungguhnya Allah menyukai orang-orang yang berlaku adil"

Kedua, kelompok yang memerangi atau merugikan kaum muslimin dengan berbagai cara. Terhadap kelompok ini tidak boleh dijalin hubungan yang harmonis, tidak boleh juga didekati. Kelompok inilah yang dimaksudkan oleh Allah untuk tidak dijadikan Auliya'.

Ketiga, kelompok yang secara tidak terang-terangan memusuhi kaum muslimin, tetapi ditemukan pada diri mereka sekian indikator yang menunjukkan bahwa mereka tidak simpati terhadap kaum muslimin tetapi mereka bersimpati pada musuh-musuh islam. Kepada kelompok inilah Allah memerintahkan untuk bersikap hati-hati tanpa memusuhi.

Berkaitan dengan larangan dari ayat-ayat yang telah disebutkan diatas, M. Quraish Shihab mengatakan bahwasanya larangan tersebut tidaklah mutlak melainkan bersyarat. Larangan tersebut hanya bagi orang-orang yang memiliki sifat yang sama dengan orang kafir. Sehinggga yang dipandang bukanlah sosoknya tapi sifatnya. Seseorang yang tidak memiliki sifat sama seperti sifatnya orang kafir meskipun dia non muslim maka no problem untuk dijadikan auliya', begitu juga orang muslim selama dia memiliki sifat-sifat tersebut maka maka tidak boleh dijadikan auliya'. Diantara ciri-ciri tersebut yaitu: pertama, karena mereka memperolok-olok agama atau melecehkan agama sebagaimana disebutkan dalam QS. al-Maidah ayat 57. Kedua, mereka berupaya menjadikan orang islam untuk berpaling dari agamanya menuju kekufuran atau minimal telah tertanam dalam lubuk hati orang islam keraguan terhadap keyakinan tersebut sebagaimana QS. al-Baqarah ayat 109. Ketiga, bakhil dan menyuruh orang berbuat bakhil sebagaimana QS. an-Nisa' ayat 37. Keempat, makan riba dan makan harta orang lain secara 
batil sebagaimana QS. an-Nisa' ayat 161. Kelima, memandang baik perbuatan jahat yang mereka lakukan sebagaimana QS. al-An'am ayat 122.

Dari penjelasan diatas merupakan perspektif hukum islam, Beda halnya ketika mengacu terhadap Undang-Undang di Indonesia yang berhubungan dengan kepemimpinan, maka selama memenuhi syaratsyarat yang telah di paparkan diatas berkesimpulan bahwa siapa saja orang yang memenuhi syarat-syarat dan prosedur pemilihan yang telah dipaparkan diatas tanpa membedakan ras, suku dan agama dinyatakan sah dan memiliki kekuatan hukum. Karena Indonesia memiliki asa Bheneka Tunggal Ika yaitu lebih menekankan terhadap kesatuan rakyat tanpa fanatik terhadap suku, ras, maupun agama.

Selain hal tersebut lantas bagaimana hukum menggunakan hak suara untuk non muslim. Ternyata dalam hal ini ikut terhadap apakah boleh non muslim menjadi pemimpin. Karena penggunakan hak suara itu merupakan wasilah dari suksesnya pemilihan pemimpin tersebut, sementara wasilah itu sama hukumnya dengan tujuannya yang mana dalam hal ini adalah terpilihnya non muslim sebagai pemimpin.

Dalam hal ini al-Razi menggolongkan keadaan muslim yang mengangkat non muslim sebagai wali ada 3 bagian: Pertama, dia rido terhadap kekafirannya dan memilih dia sebagai pemimpin karena kekafirannya tersebut dan ini dilarang karena akan menyebabkan kekafiran dengan beralasan bahwa orang yang rido dengan kekafiran itu juga tergolong kafir. Kedua, sebatas pergaulan yang baik saja secara dohir, dalam artian tidak meridoi terhadap kekafiran tersebut. Dalam golong yang kedua ini tidaklah dilarang oleh syara'. Ketiga, golongan ini diantara kedua golong diatas. Dalam golongan ini dia mengangkat tersebut dengan arti percaya kepada orang tesebut dan menolongnya disebabkan orang tersebut merupakan kerabatnya atau mencintainya dengan tetap meganggap bahwa agamanya salah. Perlakuan dari golongan ini juga dilarang meskipun tidak menyebabkan terhadap kekafiran seperti halnya golongan pertama karena mengangkat non muslim sebagai pemimpin dengan alasan tersebut terkadang mengantarkan kepada memberikan ruang lingkup terhadap mereka dan rido terhadap agamanya yang dapat mengeluarkan seseorang muslim dari keislamannya.

Sejalan dengan pendapat al-Razy yaitu imam Nawawi banten yang sama-sama membagi 3 golongan orang yang memilih pemimpin non muslim sebagai pemimpin. Yang yang sama-sama mengatakan kebolehan bagi golongan yang kedua sebagaimana yang dikatan oleh al-Razy. Dalam golongan kedua ini imam nawawi banten menyebutkan bahwa pada golongan kedua ini yaitu sebagai bentuk dari pada pergaulan yang baik di 
dunia tapi sebatas dahir saja sehingga perbuatan yang seperti ini tidak dilarang.

\section{H. Simpulan}

Dari hasil pembahasan dapat diambil kesimpulan sebagai berikut; Pertama, Ulama' masih berbeda pendapat terkait dengan kebolehan non muslim menjadi pemimpin. Perbedaaan tersebut yaitu: Pertama tidak boleh, kedua boleh pada ranah eksekutif saja. Kedua, Bagi kaum muslim memilih non muslim sebagai pemimpin hukumnya sama dengan hukum non muslim menjadi pemimpin dan ketiga, boleh bersyarat.

\section{DAFTAR PUSTAKA}

Ainun Najib, Emha. Demokrasi La Raiba Fih. Jakarta: Penerbit Buku Kompas, 2009.

Al-Mawardi, al-Ahkam al-Suthaniyyah. Mesir: Musthafa, 1973.

al-Nawawi al-banteny, Muhammad Ibn Umar. Murah Libaidi Likasyfi Makna Al-Qur'an Al-Majid. Bairut: Dar al-Kutub Ilmiyyah, 1988.

al-Razy, Fahruddin. Mafatih al-Ghoib. Bairut: Dar Ihya' al-Turats al-Araby, 1983.

Aristoteles, Politik (La Politika). Jakarta:Visimedia, 2007.

Audah, Abdul Qadir. al- Mal wal Hukmi fi al-Islam. Bairut: Mansyurat alAshar, 1971.

Daud, Abu. Sunan Abi Daud. Lebanon: Darul Kutub, jilid II, 1996.

Dayya'u al-Din al-Rais, Muhammad. al-Nadariyyah al-Siyyasiyyah alIslamiyyah. Kairo:Dar al-Turats, 1976.

Ismail, Yahya. Manha as-Sunnah fi al-Alaqoh baina al-Hakim wa alMahkum. Mansurah:Dar al-Wafa',1994.

Prasetyo, Eko. Demokrasi Tidak Untuk Rakyat. Yogyakarta: Resist Book, 2005.

Rizkiyansyah, Ferry Kurnia, Mengawali Pemilu Menatap Demokrasi (Catatan Penyelenggaraan Pemilu 2004). Bandung: Idea Publishing, 2007

Shabirin, Thabrani. Mengantar Bangsa Menuju Demokrasi. Jakarta: KPULPSI, 2000.

Shihab, M. Quraisy. Tafsir al-Misbah. Tangerang: Lentera Hati, 2005.

Syarif an-Nawawy, Abu Yahya Muhyiddin . Raudah at-Thalibin wa Umdah al-Muftiin. Bairut: al-Maktabah al-Islamy, 1991.

Syarif, Mujar Ibnu. Doktrin dan Pemikiran Politik Islam. Bandung: Erlangga, 2008.

76 JURNAL LISAN AL-HAL 
Taimiyyah, Ibnu. as-Syiyasyah as-Syar'iyyah Islah ar-Ra'yi wa ar-Arraiyyah. Riyadh: Maktabah salafiyyah wa Maktabatuha, 1964.

Zakariyya an-Nadaf, Muhammad. al-Akhlak al-Siyasiyyah li al-Daulah alIslamiyyah. Damaskus: Dar al-Qalam, 2006. 
"Kepemimpinan Non Muslim"

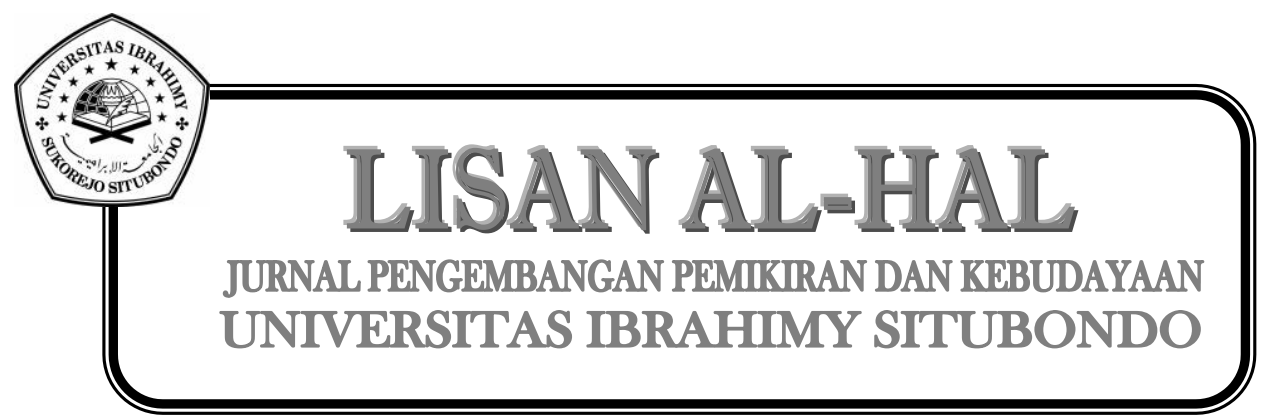

78 JURNAL LISAN AL-HAL 